\title{
Malaysian Graduates English Adequacy in the Job Sector
}

\author{
Gopala Krishnan Sekharan Nair (Corresponding author), Rozlan Abdul Rahim, Roszainora Setia, Norhayati \\ Husin, Elangkeeran Sabapathy, Nur Amalia Abd Jalil, Razifa Mohd Razlan, Razita Mohamad, Shahidatul \\ Maslina Mat So'od \& Nurul Izatee Md Yusoff \\ Academy of Language Studies, Universiti Teknologi MARA (UiTM) \\ Dungun Campus, 23000 Dungun, Malaysia
}

Tel: 60-9-8400-8225/60-12-900-2602 E-mail: gopal792@tganu.uitm.edu.my

Nor Madihah Mohamed

Sultan Sulaiman Secondary School, 24000 Kemaman, Terengganu, Malaysia

E-mail: nmadihah5@yahoo.com

Norhafiza Abu Seman

Faculty of Administrative Science and Policy Studies, Universiti Teknologi MARA (UiTM)

Dungun Campus, 23000 Dungun, Terengganu, Malaysia

Received: December 30, 2011

Accepted: January 30, $2012 \quad$ Published: April 1, 2012

doi:10.5539/ass.v8n4p143

URL: http://dx.doi.org/10.5539/ass.v8n4p143

\begin{abstract}
Historically, the use of the English Language in Malaysia, then Malaya, dates back to the Colonial times. This shows there has been a legacy of English usage in the nation. Recently, in view of globalization and increasing competition among nations in the world, there has been a renewed emphasis on the importance of English. This study hopes to provide some feedback from four industries in Kemaman about the adequacy of our new graduates. This study focused on two GLCs and two private sector companies in Kemaman, Terengganu. However, the findings can be applicable to companies throughout the country, be they GLC's, government or private sector. Although only 115 respondents from the supervisory level upwards have been selected as the sample, these 115 respondents can be representative of the work sector not only in Kemaman, Terengganu but in the entire nation. Based on the findings, the speaking, writing, social skills and overall English proficiency of new graduates were found to be not adequate. Future researchers should focus on the need for a new syllabus design which gives scope for the development of soft skills such as interpersonal skills, speaking skills and socializing skills.
\end{abstract}

Keywords: GLC, Working need, Job market, Language skills, Social skills

\section{Introduction}

This study aimed to find out whether the work sector finds the English Language proficiency of the new graduates is adequate to need of the workplace. The focus is to identify whether lack of English proficiency will contribute to poor market value among new graduates and it is hoped that the findings would help the ministry in modifying the curriculum to be in tune with the needs of the job market. This study aimed to find out which aspect of the language proficiency skills that has been found wanting by the work sector. It is hoped that this feedback would be useful to policy planners and curriculum designers in coming up with English curriculum which will be in tandem with the needs of the job market.

The advent of Information Technology and globalization has made English Language proficiency imperative for most countries in the world especially the developing countries. Foreign investors appear to prefer English speaking countries. In the past, the Malaysian economy was based on commodities such as rubber, tin and oil palm. In the 80's, the focus of the Malaysian economy shifted from the agriculture sector to the industrial sector. In response to this new development, the government has correctly emphasized on the learning of English to facilitate the acquiring of new knowledge and skills so that a knowledge-based economy would be in place. 
Globalization has put all nations on a competitive level and organizations both public and private are seeking to get more competent graduates who are skilled in the language. Therefore, this study focuses on whether the products of the education system have a level of language competency which is adequate to the needs of the job sector.

McDonough, (1997) advocates getting feedback from the work sector. This is what this study hopes to achieve. Jerrems, (2006) said that the lack of English proficiency has many consequences including occupational segregation. It is the fact that poor English proficiency may affect employment prospect.

\section{Literature Review}

\subsection{The importance of English}

According to Nich, (2005), long before the diversification in degree programs that we see now, an English qualification was the most assured ticket of success at the workplace. Newman et. al. (1997), mentioned the importance of cognitive, affective, instructional, curricular, and school-based factors which are vital for English speaking and reading skills. However, they stressed the need for curriculum to take into account the pragmatic requirements when designing curriculum.

\subsection{English Proficiency and Career Success}

English is now a global language. All over the globe including France and Germany, people are clamoring to learn English. Academics have no dispute with the view that English Language is related to success in career. Mahmoud A. Al-Khatib, (2005) from the University of Auckland, New Zealand has studied the use of English by tourism and banking personnel and attempted to examine the communication needs of the personnel in the workplace by seeking their opinions on their perception of what constituted English which is deemed adequate to the workplace. Another author Shanta Nair-Venugopal (2000), in an article titled, 'English, identity and the Malaysian workplace' has found out that English is increasingly important in the workplace. According to Chowdhury (2005), "Quality is defined by the customers". In this case, the customers are the work sector and are the appropriate party to assess the quality of the English of the new graduates.

Ball and Chik (2001), stated that successful school leavers upon completing their higher learning session, would seek various employment opportunity in the job market. They found a significant relationship between income levels and gender, duration of employment, self-esteem, ownership, academic major and "English proficiency".

\section{Methodology}

\subsection{Research Design}

Zikmund (2003), stressed the need of the research design in carrying out research. As this study involves both descriptive and inferential statistics, a survey was carried out using a set of questionnaire. Sekaran (2003) defined the questionnaire as a pre-formulated written set of questions. The instrument for this study was self-developed. The instrument was intended to elicit answers with which all the research questions can be answered.

\subsection{The Questionnaire}

According to Malhotra and Naresh (2004), there are two types of questions; structured and unstructured questions. The questionnaire for this study will elicit both ordinal and nominal data. The instrument will be pilot tested prior to its use.

\subsection{Population and Sampling procedure}

In this study the population is taken to mean the staff of government linked companies (GLC's) and private agencies around Kemaman district in Terengganu. Out of this target population, a sample of 115 was selected which consisted of 70 respondents from the private sector while 45 respondents were from the GLC's. Questionnaires was distributed and later collected and analyzed.

\section{Results and Discussion}

\subsection{Answering Research Questions}

Research Question 1: Does the job market find the speaking skills of the new graduates adequate to the working need?

$<$ Insert Table 1 Here $>$

Table 1 shows the score of the speaking skills of the new graduates. In term of perception of the sample, the score is only $60.6 \%$. Therefore, it can be concluded that the new graduates do not have speaking skills which is appropriate to the working need.

Research Question 2: Does the job market find the writing skills of the new graduates adequate to the working 
need?

$<$ Insert Table 2 Here $>$

The table above shows the score of the writing skills of the new graduates. The score is only $64.2 \%$ as responded by the samples. Therefore, the new graduates do not have writing skills which is adequate to the working need.

Research Questions 3: Does the job market find the social skills of the new graduates adequate to the working need?

$<$ Insert Table 3 Here $>$

Table 3 shows that the score of the social skills of the new graduates only amounted to $60.9 \%$ according to the perception of the sample. Therefore by the definition of this study, the new graduates do not have social skills adequate to the working need. This is not surprising as the social skills are much related to listening and speaking skills. If a person does not have adequate speaking and listening skills, there may be problems with the interaction skills which are the cornerstone of social skills.

Research Question 4: Does the job market find the overall proficiency level of the new graduates adequate to the working need?

$<$ Insert Table 4 Here $>$

Table 4 shows the mean scores as obtained from the 115 respondents for the four main language skills as well as the social skills of the new graduates. Additionally, the mean for the overall English proficiency is also shown. As can be seen from table 4 above, the overall English proficiency score is 147.5 or $64.1 \%$ of the total mean possible. Therefore, it is found that the job market does not find the overall proficiency level of the new graduates adequate to the working need. However, the reading skill is found to be adequate to the working need as the score of $72.3 \%$ was obtained and this is more than the needed $70 \%$ benchmark set for this study. This is not surprising as reading is a receptive skill and most new graduates are better in the receptive skills compared to the productive skills

\section{Conclusion}

In conclusion, the new graduates in Malaysia are not proficient in English Language. They are still not widely marketable in the job market due to a lack of English proficiency and this is costing the nation a great deal of money. Money save on retraining programs can be utilized elsewhere like upgrading libraries around the country. Graduates with good English proficiency are vital manpower in the nation's quest to create a K-economy where the knowledge of the populace would be a pulling factor in attracting foreign direct investment.

Malaysia would be hard put to compete with more advanced and well established manufacturing industries in a liberalized economy which frowns on trade protectionism. The best alternative would be to fortify a knowledge based service industry and this requires a sound knowledge of English. Thus, it can be seen the learning of English in not merely for the sake of social vanity, it is related to our economic survival in the post 2000 era of globalization. The education system should take serious steps to improve the soft skills of the students. According to newspaper reports, employers frequently lament that many recent graduates lack vital soft skills such as interpersonal skills, communicating skills, negotiating skills, persuading skills and other vital skills inherent in communication.

Curriculum designers and policy planners should review the current syllabus which emphasizes on work book drilling to master grammatical accuracy. As a result of this mode of learning, students are at the loss when it comes to real world communication. There is a need to improve students' fluency by a curriculum which gives ample opportunities for a student to develop interpersonal and presentation skills. The education system should emphasize fluency over accuracy and provide students with plenty opportunities to do presentations and role plays. Exercises of this sort would remove the speaking inhibition and increase the students' level of fluency, which would stand him in good stead when he enters the job sector. Accuracy of language and grammar should be introduced inductively by greater exposure to listening and reading. Consistent reading can improve grammar inductively. This was shown by Elley, W. B. (1991) in his book flood studies. There is a need for policy planners and curriculum designers to go back to the drawing board. We may be producing graduates who are sufficiently knowledgeable in their area of study but inadequate in English Language proficiency and the soft skills which depend on sound English proficiency.

\section{References}

Ball, R. \& Chik, R. (2001). Early employment outcomes of foreign and educated graduates the Malaysian Experience. Higher Education Publisher: Springer Netherlands, Vol. 42, No. 2, September, pp. 171-189. 
Chowdhury, S. (2005). The Ice Cream Maker: An Inspiring Tale About Making Quality the Key Ingredient In Everything You Do, U.S.A.

Elley, W. B. (1991). Acquiring Literacy in a Second Language: The effect of book-based programmes. Language Learning, 41(3), 375-411. http://dx.doi.org/10.1111/j.1467-1770.1991.tb00611.x

Jerrems VL. (2006). Asian Americans and Bilingual Education: Critical Themes in Considering the Unz Initiative. Retrieved 4th April, 2006, from http://www.sscnet.ucla.edu/aasc/unz/biblio.html

Mahmoud A. Al-Khatib. (2005). English in the Work Place: An Analysis of the Communication Needs of ]ournalism and Banking Personnel. Asian EFL-Journal, Vol. 7, No. 2, Article 11. University of AucklandFaculty of Arts.

Malhotra, Naresh K. (2004). Marketing Research (4 ${ }^{\text {th }}$ Ed.). Pearson Education, Inc., New Jersey, USA.

McDonough, J. (1997). Research Methods for English Language Teaching. Retrieved $3^{\text {rd }}$ April, 2006, from http://books.google.com.my/books?q=research+the+important + of + English $+\&$ oi $=$ print

Nich, C. (2005). Contributing writer to World Wide Learn. References: Bureau of Labor Statistics, U.S. Department of Labor, Occupational Outlook Handbook, 2004-05 Edition.

Sekaran, U. (2003). Research Methods for Business - A Skill Building Approach $\left(4^{\text {th }}\right.$ Ed.). John Wiley \& Sons, Inc., USA.

Shanta Nair-Venugopal. (2000). English, identitv and the Malaysian workplace. World Englishes, Vol. 19, No. 2, July, p. 205. Universiti Kebangsaan Malaysia. http://dx.doi.org/10.1111/1467-971X.00169

Susan B. Newman \& David K. Dickinson. (1997). Retrieved $3^{\text {rd }}$ April, 2006, from http://books.google.com.my/books?q=research+the+important + of + English $+\&$ oi $=$ print

Zikmund. W. G. (2003). Business Research Methods ( $7^{\text {th }}$ Ed.). South Western, USA.

Table 1. Speaking Skills of the New Graduates at the Workplace

\begin{tabular}{c|c}
\hline $\begin{array}{c}\text { Component of } \\
\text { English Skills }\end{array}$ & $\begin{array}{c}\text { Mean Percentage } \\
\text { against maximum } \\
\text { mean }\end{array}$ \\
\hline Speaking & 60.6 \\
\hline
\end{tabular}

Table 2. Writing Skills of the New Graduates at the Workplace

\begin{tabular}{c|c}
\hline $\begin{array}{c}\text { Component of English } \\
\text { Skills }\end{array}$ & $\begin{array}{c}\text { Mean Percentage } \\
\text { against maximum } \\
\text { mean }\end{array}$ \\
\hline Writing & 64.2 \\
\hline
\end{tabular}

Table 3. Social Skills of the New Graduates at the Workplace

\begin{tabular}{l|c}
\hline \multicolumn{1}{c|}{ Component of English Skills } & Mean Percentage against maximum mean \\
& \\
\hline Listening & 65.6 \\
Speaking & 60.6 \\
Social & 60.9 \\
\hline
\end{tabular}


Table 4. Workplace Perception of the Various English Language Skills of the New Graduates

\begin{tabular}{l|c|c}
\hline $\begin{array}{c}\text { Language } \\
\text { Component }\end{array}$ & Mean & $\begin{array}{c}\text { Mean } \\
\text { Percentage } \\
\text { against } \\
\text { maximum mean }\end{array}$ \\
\hline Listening & 32.8 & 65.6 \\
Speaking & 30.3 & 60.6 \\
Reading & 28.9 & 72.3 \\
Writing & 28.9 & 64.2 \\
Social & 27.4 & 60.9 \\
Overall & 147.5 & 64.1 \\
Proficiency & & \\
\hline
\end{tabular}

